\title{
An early Late Triassic long-necked reptile with a bony pectoral shield and gracile appendages
}

\author{
Jerzy Dzik and Tomasz Sulej \\ Acta Palaeontologica Polonica 61 (4), 2016: 805-823 doi:http://dx.doi.org/10.4202/app.00276.2016
}

Several partially articulated specimens and numerous isolated bones of Ozimek volans gen. et sp. nov., from the late Carnian lacustrine deposits exposed at Krasiejów in southern Poland, enable a reconstruction of most of the skeleton. The unique character of the animal is its enlarged plate-like coracoids presumably fused with sterna. Other aspects of the skeleton seem to be comparable to those of the only known specimen of Sharovipteryx mirabilis from the latest Middle Triassic of Kyrgyzstan, which supports interpretation of both forms as protorosaurians. One may expect that the pectoral girdle of S. mirabilis, probably covered by the rock matrix in its only specimen, was similar to that of $O$. volans gen. et sp. nov. The Krasiejów material shows sharp teeth, low crescent scapula, three sacrals in a generalized pelvis (two of the sacrals being in contact with the ilium) and curved robust metatarsal of the fifth digit in the pes, which are unknown in Sharovipteryx. Other traits are plesiomorphic and, except for the pelvic girdle and extreme elongation of appendages, do not allow to identify any close connection of the sharovipterygids within the Triassic protorosaurians.

Key words: Archosauromorpha, Sharovipteryx, protorosaurs, gliding, evolution, Carnian, Poland.

Jerzy Dzik [dzik@biol.uw.edu.pl], Instytut Paleobiologii PAN, ul. Twarda 51/55, 00-818 Warszawa, Poland and Wydział Biologii Uniwersytetu Warszawskiego,

Centrum Nauk Biologiczno-Chemicznych, ul. Żwirki i Wigury 101, 02-089

Warszawa, Poland. Tomasz Sulej [sulej@twarda.pan.pl], Instytut Paleobiologii PAN, ul. Twarda 51/55, 00-818 Warszawa, Poland.

This is an open-access article distributed under the terms of the Creative Commons Attribution License (for details please see creativecommons.org), which permits unrestricted use, distribution, and reproduction in any medium, provided the original author and source are credited. 
FoF Full text $(2,143.0 \mathrm{kB})$

FOF Supplementary file $(18.6 \mathrm{kB})$ 